\title{
Large-scale, low-frequency oceanographic effects on kelp forest succession: a tale of two cohorts
}

\author{
M. J. Tegner', P. K. Dayton, P. B. Edwards, K. L. Riser \\ Scripps Institution of Oceanography, University of California, San Diego, La Jolla, California 92093-0201, USA
}

\begin{abstract}
Two catastrophic-scale storm disturbances of a giant kelp forest community were followed by very different oceanographic conditions, the warm, nutrient-stressed period of the 1982-1984 El Nino and the cold, nutrient-rich La Nina of 1988-1989. Here we compare the fates of the 2 postdisturbance algal communities, or ' 2 cohorts', under conditions determined by large-scale, lowfrequency oceanographic events. Succession and population dynamics of the competitive dominant kelp, Macrocystis pyrifera, and understory kelps, Pterygophora californica and Laminaria farlowi, were followed at 5 permanent sites in the Point Loma kelp forest near San Diego, California, USA, where kelps have been mapped quarterly since 1983. There was intense kelp recruitment after both disturbances. The different oceanographic conditions, however, strongly affected the population dynamics of $M$. pyrifera and its competitive interactions with the lower standing species. Poor $M$. pyrifera growth, canopy formation, and survival during the El Nino apparently allowed the persistence of understory populations. Extraordinary conditions for M. pyrifera growth during the La Nina were associated with the near extinction of understory populations. The number of stipes per plant and stipe density are indices of $M$. pynfera growth and carrying capacity, respectively, which appear to be very sensitive to environmental conditions. The 2 cohorts exhibited very different stipe patterns. In both cases, the anomalous oceanographic conditions lasted for about 2 yr after the disturbances, but the effects on kelp community structure persisted for the lives of the $M$. pyrifera cohorts, despite average or relatively poor conditions later In summary, these data suggest that large-scale, low-frequency oceanographic phenomena are important to kelp forest successional processes, population dynamics, and competitive interactions among kelp guilds.
\end{abstract}

KEY WORDS: El Niño $\cdot$ Kelp forest - Kelp harvest $\cdot$ La Niña $\cdot$ Macrocystis $\cdot$ Nutrients $\cdot$ Succession · Temperature - Understory kelps

\section{INTRODUCTION}

The role of interannual variability in oceanographic conditions is seldom apparent in the large body of literature describing benthic disturbance and subsequent recovery (e.g. Giller et al. 1994). For the benthos, small-scale biological interactions have been the primary focus of disturbance studies, and recent theory has focused on various attributes of a newly created patch such as size, shape, location, and season of creation in colonization, succession, and ensuing community structure (Sousa 1985). Important themes have also dealt with the characteristics of the disturbance

·E-mail: mtegner@ucsd.edu regime, including its areal extent, intensity, frequency, and seasonality, and the role of among-patch dynamics as they affect developing community structure (Connell \& Keough 1985). In contrast, pelagic systems are widely perceived to be physically driven by largescale, low-frequency events such as El Niños (e.g. Chelton et al. 1982) or the decadal-scale climate events recently documented in at least 5 pelagic ecosystems of the Pacific Ocean (e.g. Graham 1994, Polovina et al. 1994, Hayward in press). While in part these different approaches and scales at which structuring processes are perceived are driven by the tools and practical difficulties of working in the 2 environments, there can be little doubt that both large- and small-scale processes are important in both systems. Large-scale oceanographic variability and the dynamics that it generates 
in benthic systems remain poorly understood (Hall et al. 1994, Boero et al. 1996).

Like other benthic systems, studies of succession in kelp forests have focused on small-scale biological interactions and seasonal variation (Foster 1975a, b, Kennelly $1987 \mathrm{a}$, b), although 1 study considered recovery patterns over a spatial scale of $140 \mathrm{~km}$ within $1 \mathrm{yr}$ (Kennelly \& Underwood 1993). The role of large-scale interannual variability on patterns of succession is of particular interest in kelp forest communities because of their strong sensitivity to oceanographic conditions (Dayton et al. 1984, 1992, North et al. 1986, Tegner et al. 1996). Two recent catastrophic-scale disturbances of giant kelp Macrocystis pyrifera, the competitive dominant in southern California (USA) kelp forest communities, offered a rare opportunity to compare successional processes under very different oceanographic regimes. Both the extraordinary series of storms in winter $1982-1983$ (Seymour et al. 1984) dnd a massive single storm in 1988, estimated to be a $200 \mathrm{yr}$ storm by coastal engineers (Seymour 1989, Seymour et al. 1989), caused massive mortalities of $M$. pyrifera and understory kelps; successional processes werc restarted and cohorts that recruited after these disturbances faced little or no competition from pre-existing plants. While El Niño events have a variety of effects on southern California kelp forest communities, notably on animal populations (reviewed by Tegner \& Dayton 1987, Dayton \& Tegner 1990), the most relevant effect for kelp succession appears to be the temperature/nutrient regime. Here we use data from a long-term monitoring program (Dayton et al. 1992, Tegner et al. 1996) to describe how successional processes within the Point Loma (San Diego, CA) kelp forest community were apparently altered by unusual oceanographic events following the disturbances, the warm, nutrient-stressed 1982-1984 El Niño and the cold, nutrient-rich 1988-1989 La Niña. These largescale, low-frequency climatic events influenced kelp forest community structure for several years after the events themselves.

Giant kelp forests are characterized by a high degree of spatial and temporal variability, and environmental forcing clearly plays a large role in this variability (reviewed by North et al. 1986, Murray \& Bray 1993). Temperature, nutrients, light, water motion, substrata, and sedimentation are critical physical factors for kelps, important in both disturbance and recovery. The biological factors defining dispersal capabilities, recruitment, competition, and grazing are also central to patterns of succession. Physical and biological factors interact over a range of scales, e.g. the seasonality of water movement, substrate availability, and kelp life histories. Many factors affecting Macrocystis pyrifera population dynamics, such as mortality rates or susceptibility to different types of grazing or stress, are highly age dependent (Dayton et al. 1984, 1992, North et al. 1986, Tegner et al. 1995b); here the largescale disturbances acted to reduce variability in population structure, as the ensuing stands of giant kelp were very similar in age.

The effects of environmental factors on the germination, recruitment, growth, and survivorship of small, easily-studied juvenile stages of giant kelp are well established (Devinney \& Volse 1978, Wheeler \& North 1980, Dean \& Jacobsen 1984, 1986, Deysher \& Dean 1984, 1986a, b, Schroeter et al. 1995), and there is information on the effects of low nutrient conditions on adult Macrocystis pyrifera survival and growth (Gerard 1982, North \& Zimmerman 1984, Zimmerman \& Kremer 1984, 1986, Zimmerman \& Robertson 1985). In a recent analysis of $31 \mathrm{yr}$ of data from the Point Loma kelp forest (Tegner et al. 1996), we demonstrated a signińicant inverse relationship between annual average surface temperature and kelp harvest, a measure of the $M$. pyrifera canopy. Stipe number and stipe density, measures of giant kelp plant size and carrying capacity, respectively, were also related to surtace temperature. North et al. (1986) noted, however, that while nutrient limitation may sometimes curtail $M$. pyrifera productivity, the role of nutrient limitation in the competitive success of this dominant species has not been documented. Indeed, little is known about the integrated roles of environmental variablity and other aspects of kelp population dynamics and succession. Here we compare population dynamics of $M$. pyrifera and understory kelps under very different oceanographic conditions following catastrophic-scale disturbances at long-term sites in the Point Loma kelp forest.

\section{MATERIALS AND METHODS}

The Point Loma kelp forest (Fig. 1), generally about 8 to $10 \mathrm{~km}$ long by $1 \mathrm{~km}$ wide, is located on a broad, mudstone-sandstone terrace offshore of San Diego, California $\left(32^{\circ} 42^{\prime} \mathrm{N}, 117^{\circ} 16^{\prime} \mathrm{W}\right)$. Permanent sites are located at 18,15 , and $12 \mathrm{~m}$ depth in the center of the forest, forming a cross-shore transect, and at $18 \mathrm{~m}$ depth near the north and south ends of the forest forming (with the central $18 \mathrm{~m}$ site) a long-shore transect along a depth contour close to the outer edge. There are 4 parallel $25 \mathrm{~m}$ transects oriented perpendicular to the shore and spaced $8 \mathrm{~m}$ apart at each site. Kelps have been mapped quarterly and benthic macroinvertebrates have been censused annually along these lines since 1983. These data have been used for long-term population studies (Tegner \& Dayton 1987,1991, Dayton \& Tegner 1990, Dayton et al. 1992, Dayton 1994 , 


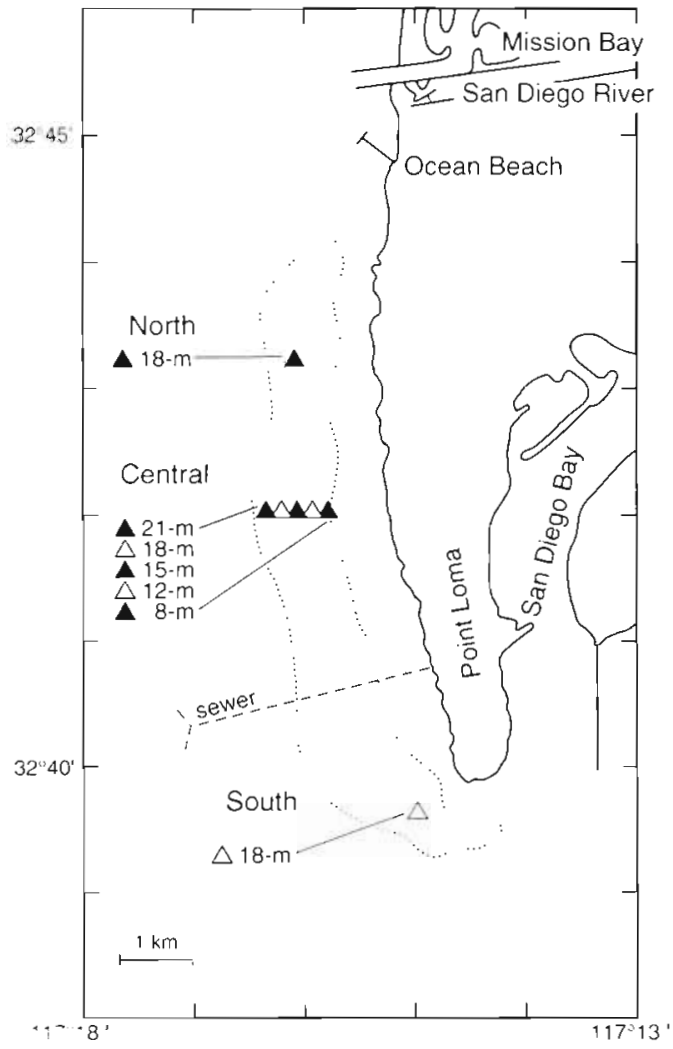

Fig. 1 Long-term study sites in the Pont Loma kelp forest (San Diego, CA, USA). The thick dotted line represents a general outline of the Macrocystis pyrifera canopy; there is considerable temporal variability. The dashed line represents the onginal $4.2 \mathrm{~km}$ San Diego sewage outfall which operated until November 1993; at that time an extension (thin dotted line), which discharges $7.2 \mathrm{~km}$ offshore, was initiated

Tegner et al. 1995a, b, 1996). While we necessarily include data from the beginning of the time series here to contrast the post-disturbance cohorts, this is the first broad-scale analysis of the transect data after 1990 , and the resulting synthesis is quite different from previous analyses.

Temperature is inversely related to the concentration of nitrate, the nutrient which limits kelp growth; nitrate is not detectable above about $16^{\circ} \mathrm{C}$ in this region (Jackson 1977, Gerard 1982, Zimmerman \& Kremer 1984). This strong inverse relationship allows use of temperature as a surrogate method to measure nitrate-nitrogen availability or nutrient stress. In situ bottom temperatures are recorded with TempMentors (Ryan Instruments, Redmond, WA, USA) and Hobo-Temp Temperature Loggers (Onset Computer Corporation, Pocasset, MA, USA). Temperatures at the long-term sites are determined every $3 \mathrm{~h}$ from the continuous record $(8$ values per day) and averaged by month. A diving quarantine imposed during a 1992 sewage outfall break (Tegner et al. 1995a) and occasional equipment failures caused some gaps in the data. Surface temperature is collected once a day in the morning from the Scripps Institution of Oceanography (SIO) pier, $12 \mathrm{~km}$ north of the entrance to Mission Bay (Fig. 1).

The Macrocystis pyrifera canopy is central to its interactions with understory algae. Two measures of the canopy are available for the Point Loma kelp forest as a whole, harvest tonnage and areal extent. The upper $1.2 \mathrm{~m}$ of the giant kelp canopy is harvested up to 3 times a year Point Loma harvest data for 1983-1994 were provided by D. Glantz of Kelco, a unit of Monsanto Company (San Diego, CA, USA). To protect proprietary information, the maximum recent harvest year (1972) was treated as $100 \%$ and other years scaled accordingly. Approximate annual maximum kelp canopy coverage data for Point Loma were compiled by W. J. North from aerial photographs (see North et al. 1993 for methods). Harvest data have advantages over aerial photography because they integrate growth over a longer period of time, with less measurement subjectivity. Areal coverage offers better spatial information, but is a snapshot in time (maximum coverage is typically in the fall) and a poor indicator of canopy density or biomass. The 2 measures are highly correlated $\left(\mathrm{r}^{2}=0.343, \mathrm{p}=0.0005\right.$ for the period 1964-1994) and both are inversely related to surface temperature, but there are differences in maximum years and in the relative value of the 2 parameters. Cooler years are associated with higher density canopies and higher harvest rates (Tegner et al. 1996).

In our study, all kelp holdfasts are mapped within $2 \mathrm{~m}$ of both sides of each transect line, so that a total of $400 \mathrm{~m}^{2}$ is surveyed at each permanent site. The maps are updated quarterly to evaluate recruitment, survivorship, and growth of individual giant kelp plants. All adult Macrocystis pyrifera (defined as 4 or more stipes per plant, Dayton et al. 1984, 1992) are mapped and stipes counted at a height of $1 \mathrm{~m}$ above the bottom; cohorts are dated from the quarter when they recruit as adults. Because recruitment, growth, and survival vary temporally among sites, the cohorts at each site are treated separately. The main goal of this paper is to compare the post-disturbance cohorts, after the 1982-1983 winter storms and after the single 1988 storm, among sites. Maximum life span for $M$. pyrifera stipes is about 6 to 9 mo (North 1971). The stipes are not tagged, so data on stipe number encompass both attrition and growth. Of the abundant understory kelps, Pterygophora californica are counted, and percent cover for Laminaria farlowii is estimated; in most cases individuals of these species are not tracked. Changes in percent cover encompass both growth and change in abundance; because of the contribution of growth to this measure, peaks in percent cover tend to be delayed 1 to $2 \mathrm{yr}$ after recruitment. Note that 
because understory kelps are censused as soon as species identification is certain but $M$. pyrifera is not mapped until it achieves 4 stipes, understory recruitment appears to precede that of giant kelp. The percent cover of understory algal groups is estimated in $5 \times 2 \mathrm{~m}$ quadrats: Cystoseira osmundacea, Desmarestia spp., brown turfs (Dictyotaceae), foliose reds, and articulated corallines

Because of their important roles as agents of disturbance at Point Loma (e.g. Dayton et al. 1992), density of sea urchins Strongylocentrotus franciscanus and $S$. purpuratus is determined annually during spring on the permanent transects at each site, or more frequently if grazing activity is apparent. Animals which can be seen with the use of a light but without disrupting individuals or the substrate are counted in 10 quadrats $(5 \times 2 \mathrm{~m})$ along the permanent lines. This procedure misses many small individuals.

\section{RESULTS}

In terms of generating interannual variability in southern California kelp populations, the critical physical parameters are water temperature (as a surrogate measure of nitrogen availability or stress), severe storms, and El Niño-Southern Oscillation events (Zimmerman \& Robertson 1985, Tegner \& Dayton 1987. 1991, Seymour et al. 1989, Dayton et al. 1992). Longterm in situ temperature records for the permanent sites in the center of the kelp forest and surface temperatures from the SIO pier are updated in Fig. 2. The
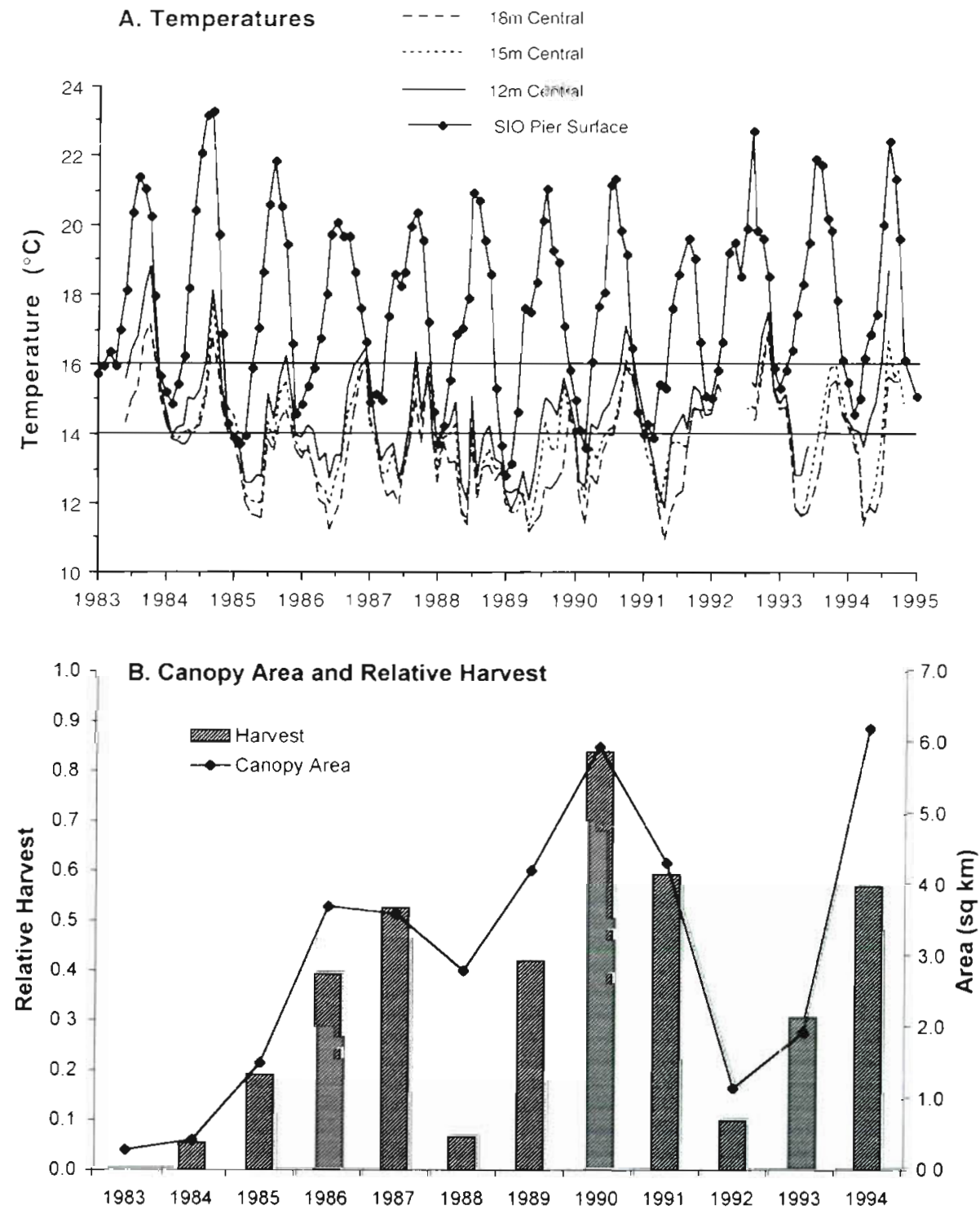

Fig. 2. (A) In situ bottom temperatures for central Point Loma and surface temperatures from the Scripps Institution of Oceanography pier, $12 \mathrm{~km}$ north of the entrance to Mission Bay, 1983 to 1994. Points represent monthly averages. A diving quarantine imposed during a 1992 sewage spill and equipment failures caused gaps in the data. Horizontal lines mark $16^{\circ} \mathrm{C}$, above which nitrate is generally undetectable, and $14^{\circ} \mathrm{C}$, the isotherm which marks the depth of the nutientdepleted surface waters at this latitude. (B) Comparison of kelp harvest data with canopy coverage for the Point Loma kelp forest, 1983 to 1994. Harvest data are scaled to the maximum recent year (1972) to protect proprietary information. Canopy coverage is calculated from aerial photography. Adapted from Tegner et al. (1996) 
in situ records reflect several patterns relevant to this discussion. First, there is a statistically significant increase in temperature with decreasing depth; the 18, 15 , and $12 \mathrm{~m}$ sites are all different from one another (Dayton et al. 1992). Second, the seasonal cycle exhibits the coldest bottom water during spring/early summer, followed by a rise in late summer/fall, and an isothermal water column during winter. Third, there is considerable interannual variability in both surface and bottom temperatures, which were heavily influenced by the 1982-1984 El Niño, the 1988-1989 La Niña, and intermittent El Nino conditions during 1992 and 1993 (Kerr 1988, Dayton et al. 1992, Hayward 1993, Hayward et al. 1994). During 1994, circulation returned to a more normal (i.e. non-El Niño) pattern, but sea surface temperatures were again anomalously warm during most of the year (Hayward et al. 1995). The $14^{\circ} \mathrm{C}$ line on Fig. 2, which indicates water with adequate nutrients, is useful for comparing in situ temperatures among years. During 1982-1983, bottom temperatures were almost exclusively warmer than $14^{\circ} \mathrm{C}$ (and for much of the time, warmer than the $16^{\circ} \mathrm{C}$ level at which nutrients are absent), whereas during the 1988-1989 La Niña, bottom temperatures were predominantly colder than $14^{\circ} \mathrm{C}$. Surface temperatures were especially warm during 1983-1985 and 19921994, and cool during 1988-1989. The strong spring upwelling observed during 1991, 1992 (Tegner et al. 1995a), 1993, and 1994 (Fig. 2), however, sharply contrasts recent temperature regimes with conditions during the 1982-1984 El Niño.

\section{Macrocystis pyrifera}

The Macrocystis pyrifera canopy cover of the Point Loma kelp forest varied considerably during the 1983-1994 period (Fig. 2). The canopy was decimated by the storm disturbances of winter 1982-1983 and January 1988, although mortality at the 5 permanent sites was higher in 1988 (Seymour et al. 1989). Note that because the time of maximum canopy area tends to be in the fall, the values of canopy coverage in Fig. 2 reflect several months of recovery. There was some degree of canopy recovery after both disturbances, but during the warm, nutrient-stressed summer/fall of both 1983 and 1984, giant kelp growth often ceased in, or fronds died back to, mid water depths (Dayton \& Tegner 1984). In contrast, the giant kelps that recruited after the 1988 storm formed extraordinary canopies during the 1988-1989 La Nina conditions, and the 1990 kelp canopy and harvest were the highest found during this study. Intermittent El Niño conditions during 1992-1993 were associated with substantial declines in both canopy coverage and harvest. Despite warm surface temperatures in 1992-1994, a sea urchin disease episode that affected the southern portion of the kelp forest starting in 1991 (Dayton et al. 1992) was followed by a major expansion of the kelp forest to the south which appeared as increased canopy coverage in 1993 and 1994. Because of the warm surface temperatures, however, harvest in 1994 was relatively low due to low stipe density (Tegner et al. 1995a, 1996).

The density of adult Macrocystis pyrifera (Fig. 3) at the 5 permanent sites illustrates the cyclical nature of its abundance in recent years. The storms of winter 1982-1983 and January 1988 caused massive levels of giant kelp mortality; the few survivors tended to be in deeper water. Strong recruitment followed both major disturbances, although the timing and magnitude of recruitment as adults ( 4 or more stipes) varied among depths and between years. For example, the delay in adult $M$. pyrifera recruitment at $12 \mathrm{~m}$ following the 1988 storm was associated with an extensive bloom of Desmarestia spp.; when the cover of this annual dropped below 20\%, the 1989 cohort of giant kelp appeared (Dayton et al. 1992). Site $18 \mathrm{~m}$ South was the major exception to this pattern because sea urchins eliminated all kelps in 1986 and did so again after the 1988 storm. Disease had killed most of these sea urchins by spring 1991 and kelp recruitment followed (Dayton et al. 1992). The resulting $M$. pyrifera population at $18 \mathrm{~m}$ South was composed of a younger cohort, and density was higher here than at any of the other permanent sites until new recruitment began elsewhere. The density of giant kelp plants at $18 \mathrm{~m}$ South peaked in fall 1992 and declined slowly thereafter (Fig. 3)

In contrast with the essentially synchronous, disturbance-induced mortality in 1988, the decline of the post-1988-storm cohorts varied among sites (Fig 3). Generally, Macrocystis pyrifera cohorts which recruited after the 1988 storm slowly declined to the point that allowed significant recruitment to take place in the second half of 1993 . The decline was faster at $18 \mathrm{~m}$ North where a sea urchin front passed through in the first half of 1993 (Fig. 4). Most of the post-1988storm kelp cohorts at $18 \mathrm{~m}$ North died before summer; the front moved on and a new $M$. pyrifera cohort recruited in late 1993 . The decline was somewhat slower at 15 and $18 \mathrm{~m}$ Central; significant new recruitment was not observed until mid 1994 at $15 \mathrm{~m}$ Central and did not take place through 1995 at $18 \mathrm{~m}$ Central (Fig. 3). Despite warm bottom temperatures, especially at $12 \mathrm{~m}$ in 1994, there was no evidence of unusual mortality that could be related to El Niño conditions; the declines in abundance resembled normal self-thinning (Dayton et al. 1984).

Fig. 5 compares survival of the first Macrocystis pyrifera cohorts after the 2 major disturbances, the 

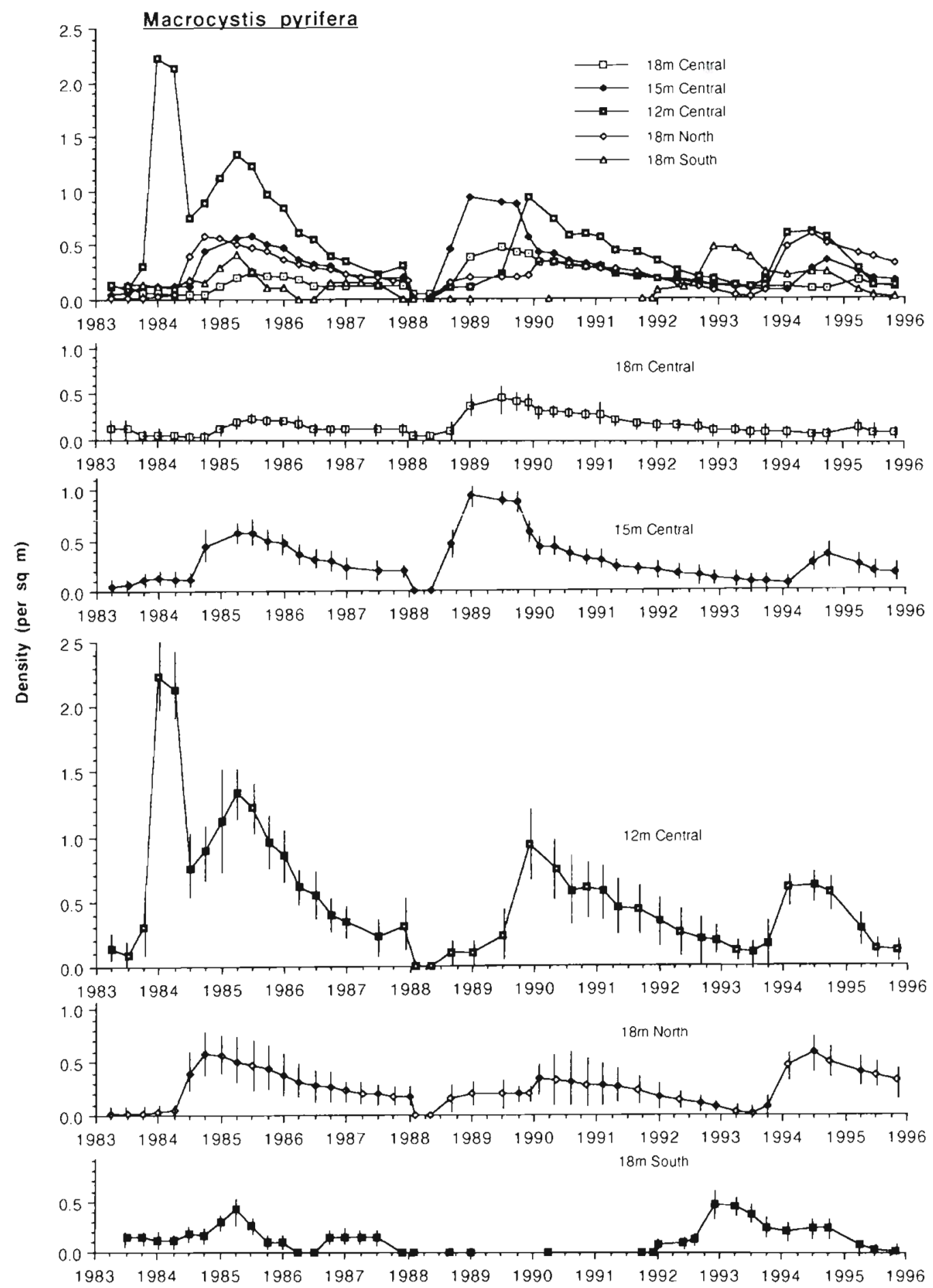

Fig. 3. Macrocystis pyrifera. Density of adult (defined as 4 or more stipes, Dayton et al. 1992) giant kelp determined quarterly at the long-term study sites, 1983 to 1995 . Error bars represent \pm 1 SD

storms of $1982-1983$ and 1988. Because both events were catastrophic in terms of their destruction of giant kelp populations, the first post-disturbance cohorts faced little competition from existing adult conspecifics. At the 3 sites where recruitment occurred immediately after the disturbances $18 \mathrm{~m}$ South became an urchin barren after the 1988 storm and $12 \mathrm{~m}$ Central was initially dominated by Des- 
marestia spp.), the summer 1988 cohorts had considerably better survival during the first 2 to $4 \mathrm{yr}$ after recruitment than the first cohorts after the winter 1982-1983 storms. This probably resulted from outstanding growth conditions (Fig. 2) during the La Nina in contrast with very poor conditions during the El Niño (Dayton et al. 1992).

The number of stipes per Macrocystis pyrifera plant indicates individual growth, and stipe density per square meter is an index of environmental carrying capacity (Dayton et al. 1992, Tegner et al. 1996). Generally there is an increase in stipe number as a plant ages superimposed over a seasonal cycle of winter decreases and spring/ summer increases in stipe number. Stipe number is also sensitive to depth, latitude, degree of wave exposure, upwelling, and other factors (Jackson 1987). Different stipe patterns were observed in the cohorts following the winter 1982-1983 storms in comparison with those after the 1988 storm. Data from 18 and $15 \mathrm{~m}$ Central are typical (Fig. 6), although both had a few adult survivors of the disturbances which led to brief peaks in the stipe per plant data before these adults died. After the extreme warm water conditions of 1983-1984, there was a steady increase in the number of stipes per plant until the catastrophic storm of 1988 (Dayton et al. 1992); presumably these plants would have continued to grow in the absence of disturbance. Stipes per plant increased as plant density decreased and thus stipe density remained relatively stable from 1986 through early 1988 at both sites. In other words, there were apparent carrying capacities of about 4 and 5 stipes $\mathrm{m}^{-2}$ at the 18 and $15 \mathrm{~m}$ sites, respectively, between 1986 and early 1988.

After the 1988 storm (excluding the pre-storm survivors), there were 3 yr (fall 1988 to fall 1991) of steady increase in the number of stipes per plant associated with the cold conditions of the 1988-1989 La Niña, then the number of stipes per plant leveled off at both sites, with the exception of seasonal variation (Fig. 6). There was widespread but intermittent sea surface warming during 1992 and 1993 associated with the
1991-1993 El Niño (Lynn et al. 1995); 1994 was also anomalously warm but with non-El Niño circulation patterns (Hayward et al. 1995). This leveling off of stipe number per plant during 3 yr of warm water conditions contrasts with the relatively steady increase observed after 1984, when water temperatures were closer to the long-term mean. The general decline in stipe density to $<2 \mathrm{~m}^{-2}$ along with the declines in plant density after summer 1991, as well as the lack of increase in stipes per plant, suggests that warm water conditions (see Fig. 2) inhibited growth and depressed carrying capacity. Thus, both plant and stipe densities were much higher in 1988-1990 than in 1985-1986, 

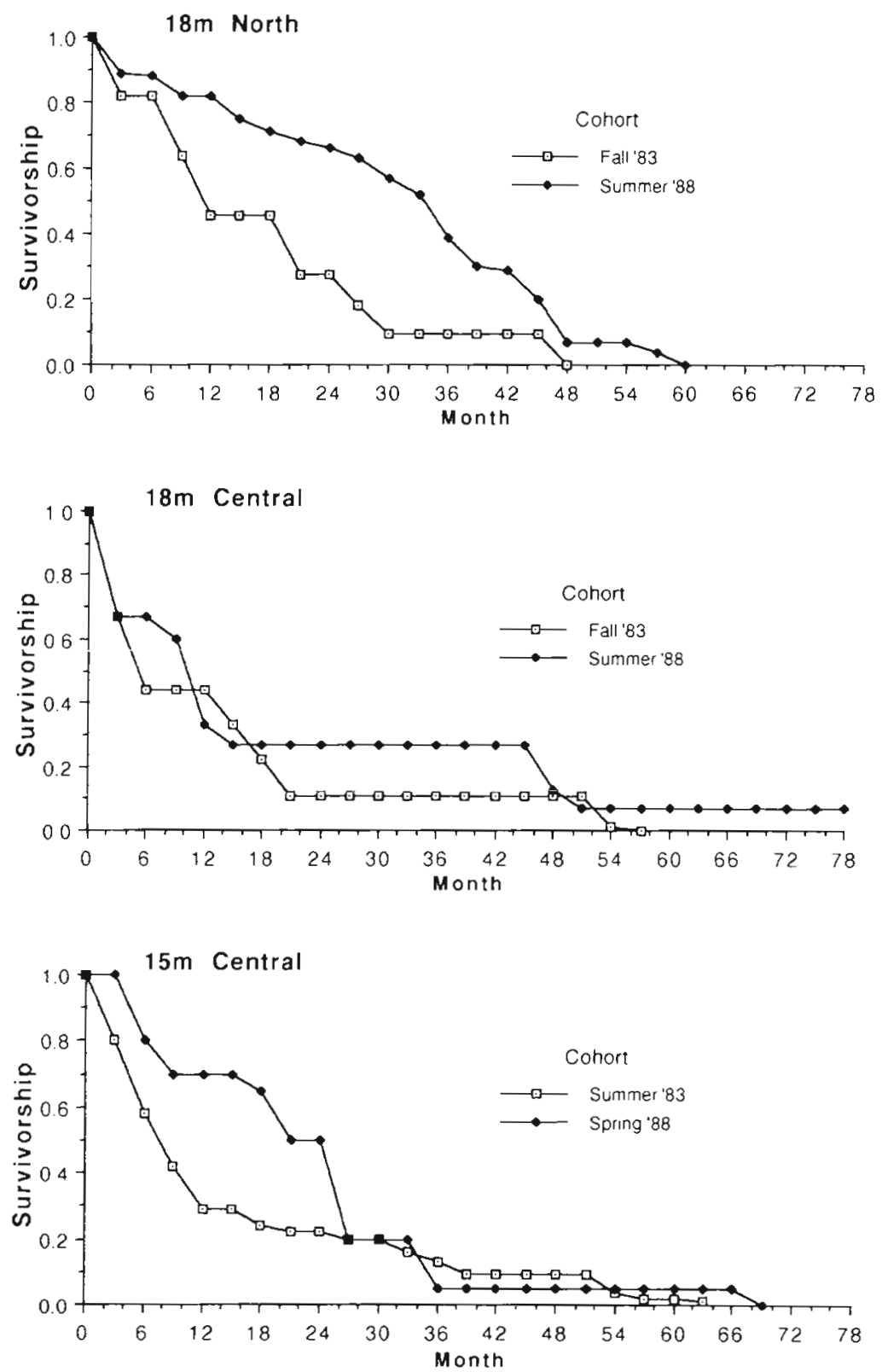

Fig. 5. Macrocystis pyrifera. Survivorship of the first cohorts after catastrophic-scale disturbances, the winter 1982-1983 storms and the January 1988 storm, at the $18 \mathrm{~m}$ North, $18 \mathrm{~m}$ Central, and $15 \mathrm{~m}$ Central sites

\section{Pterygophora californica}

Pterygophora californica, a stipitate understory kelp often outcompeted by Macrocystis pyrifera for light, is most common in shallow ( $\leq 15 \mathrm{~m}$ ) water at Point Loma (Dayton et al. 1984, 1992). Less susceptible than giant kelp to storm waves, its populations were damaged by the major disturbances but some long established patches of $P$. californica persisted through both events. Generally, its abundance surged after the 2 major disturbances, and then tapered off as giant kelp canopies recovered (Figs. 7 \& 8). There was, however, a large difference in $P$. californica persistence on the transects under the different oceanographic regimes. $P$. californica that recruited after the 1988 storm were relatively short-lived. This species underwent precipitous declines in density starting in 1990 at $15 \mathrm{~m}$ Centrai and 1991 at $12 \mathrm{~m}$ Central, and was rare or absent along the permanent transect lines in 1992-1993. Initial $P$. californica densities were lower at the $18 \mathrm{~m}$ sites, but abundance of this understory kelp also went to zero at $18 \mathrm{~m}$ Central in 1992 and $18 \mathrm{~m}$ North in 1993. In contrast, plants recruiting during the 1982-1984 El Niño persisted until the 1988 storm at all 4 of these sites, especially 12 m Central. Smaller scale P. californica responses to reductions of $M$. pyrifera were seen at $18 \mathrm{~m}$ South after the urchin grazing event in 1986, and the decline of giant kelps at $12 \mathrm{~m}$ Central in late 1993 and $15 \mathrm{~m}$ Central in 1995.

\section{Laminaria farlowii}

Laminaria farlowii is a prostrate kelp species common at all 3 study depths which is outcompeted by both Macro-

but the initial success of the post-1988-storm cohorts did not persist, and both stipe indices dropped well below the 1986-1988 average sizes and carrying capacities (Fig. 6). New plants recruited in mid 1994 at $15 \mathrm{~m}$ Central after the decline of the post-1988-storm cohorts, and data from the early stages of this cohort indicate that the plants are growing in size as plant density decreases and the stipe density has remained relatively constant at about $4 \mathrm{~m}^{-2}$ under more normal surface temperatures in 1995. cystis pyrifera and Pterygophora californica (where they co-occur) for light but is the least susceptible to storm damage (Dayton et al. 1984, 1992). Like P. callfornica abundance, $L$. farlowii percent cover peaked after the 1982-1983 and 1988 storm disturbances (Figs. 7 \& 9). There was an even more dramatic contrast between $L$. farlowii populations in years following the disturbances, however. The $\mathrm{El}$ Nino $M$. pyrifera cohorts were apparently sparse enough to allow L. farlowii peristence until the 1988 storm at all 


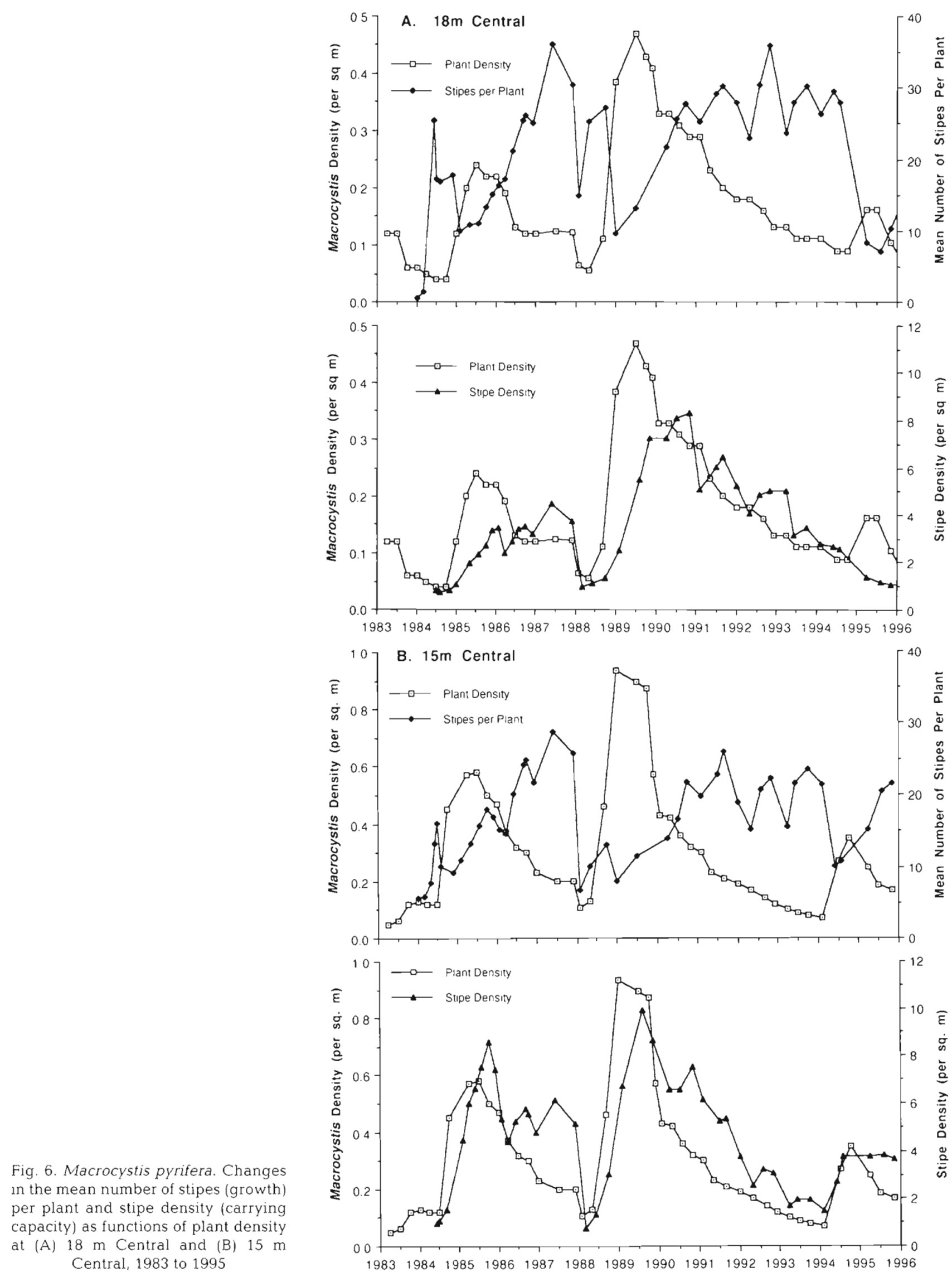



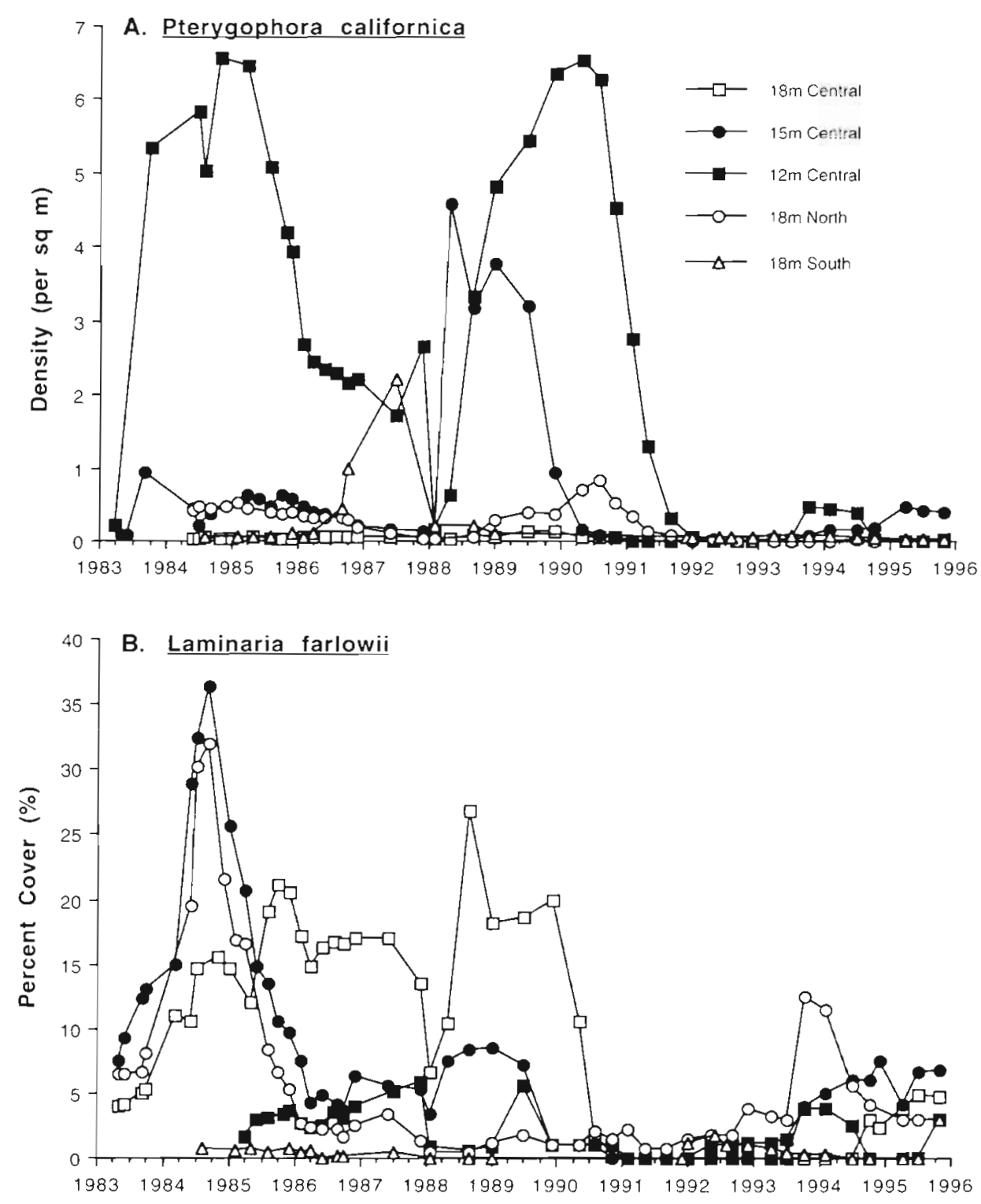

Fig. 7. Changes in (A) density of understory kelp Pterygophora californica, and (B) percent cover of understory kelp Lamjnaria farlowii, 1983 to 1995 at the 5 permanent sites

permanent sites (except $18 \mathrm{~m}$ South due to sea urchin grazing in 1986). The very cold La Niña conditions after the 1988 storm were associated with extraordinary $M$. pyrifera growth and declines in $L$. farlowil percent cover to zero at all sites between 1989 and 1991. L. farlowil was absent for intervals of 1 to $3 \mathrm{yr}$ until the decline of local $M$. pyrifera stands allowed for new recruitment.

\section{Other algae}

The other algal groups showed several patterns. The annual Desmarestia spp. responded to storm and grazing disturbances with short-term bursts in percent cover (data not shown). Cystoseira osmundacea also recruited at some sites after each major disturbance, but only persisted at trace levels in both the 1980 s and the 1990s; this is consistent with the low survivorship of cohorts of this species observed in the 1970s (Dayton et al. 1984). Coralline algae (Fig. 10A), well known for their deep distributions (e.g. Lobban et al. 1985), showed no evidence of response to the different temperature/Macrocystis pyrifera regimes nor to the 1988 storm. Foliose red algae, although they experienced major recruitment peaks at some sites during the 1983-1984 El Niño, were generally similar to corallines. Brown turf (Dictyotaceae) persistence, however, followed a pattern very similar to that of the understory kelps; these recruited strongly after both major disturbances at 18 and $15 \mathrm{~m}$ Central, persisted at low levels until the 1988 storm, virtually disappeared from mid 

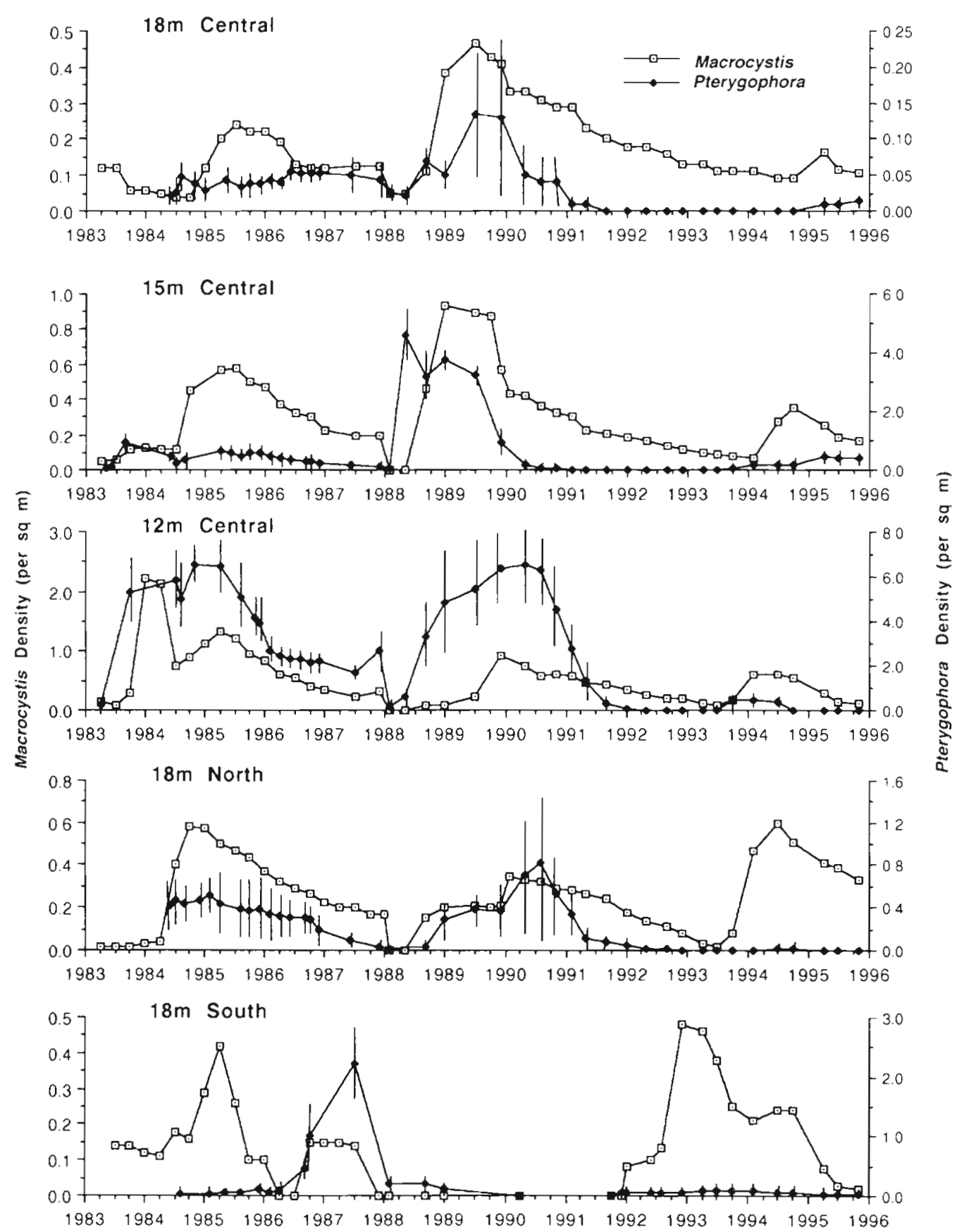

Fig. 8. Macrocystis pyrifera and Pterygophora californica. Changes in kelp densities at each of the permanent sites, 1983 to 1995 Error bars represent $\pm 1 \mathrm{SD}$. Note scale changes among species and sites

1989 through 1992, and then reappeared as post-1988storm M. pyrifera cohorts declined (Fig. 10B).

\section{DISCUSSION}

Odum (1981) compared the different trajectories of succession in environments with and without severe environmental stress. He suggested that, in the ab- sence of stress, an ecosystem achieves a higher level of organization, whereas in the presence of severe stress, the process of organization is likely to be slowed and the ultimate steady state that might be reached would be at a lower level of organization. Turkington et al. (1993), testing the hypothesis that the effects of interspecific competition would decline along gradients of decreasing nutrients and increasing disturbance among pasture plants, demonstrated that nutrients 

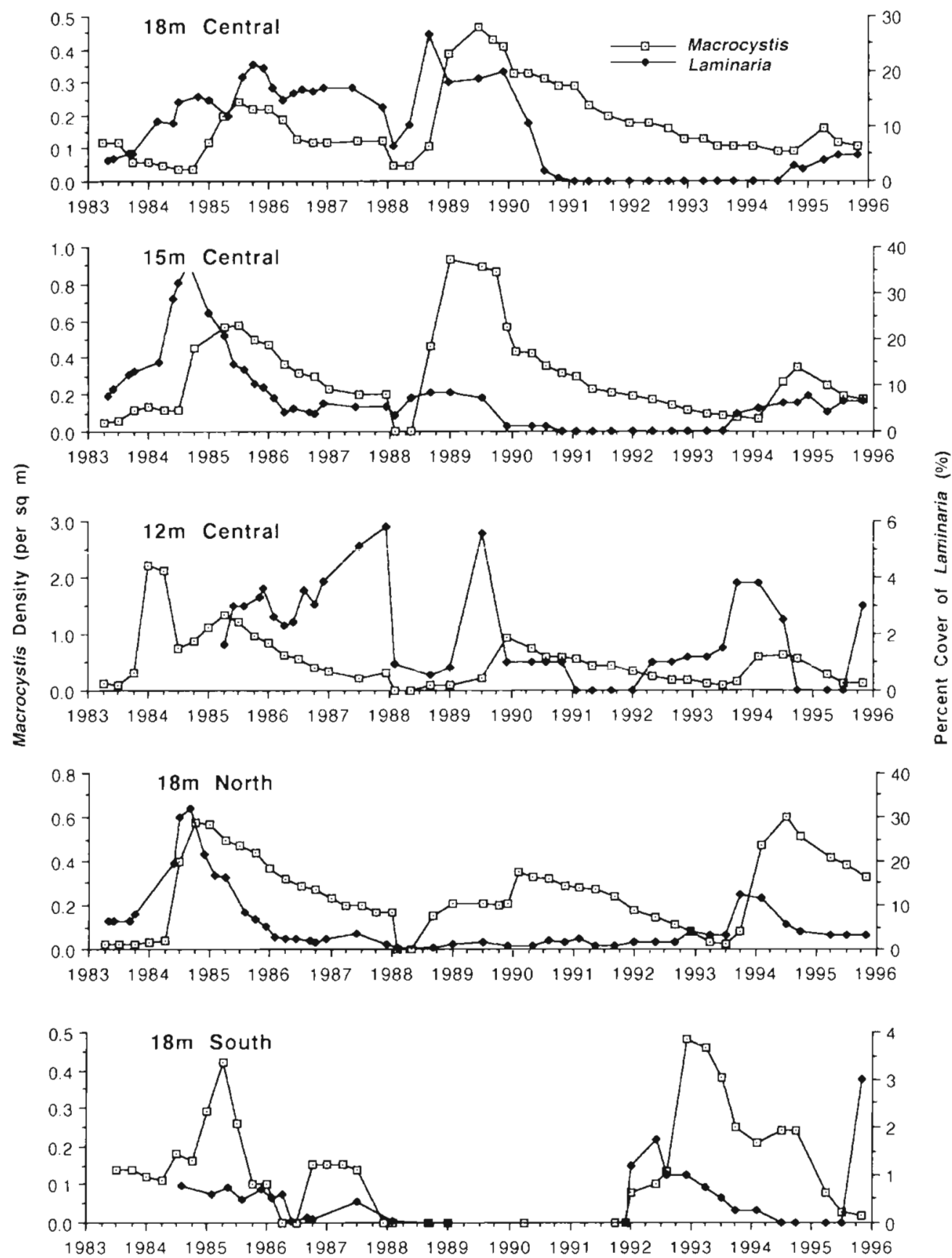

Fig. 9. Changes in Macrocystis pyrifera density and Laminaria farlowii percent cover at each of the permanent sites, 1983 to 1995. Error bars represent $\pm 1 \mathrm{SD}$. Note scale changes among species and sites

and disturbance interact to determine community structure. Here we compared succession after 2 catastrophic disturbances under contrasting oceanographic regimes, the nutrient-stressed El Niño conditions of 1983-1984 and, on the opposite end of the spectrum, the very cold, nutrient-rich La Niña conditions of 1988-1989. These different oceanographic regimes had different effects on succession, notably on the performance of the competitive dominant itself and on its competitors. In both cases the unusual oceanographic conditions lasted for about $2 \mathrm{yr}$, but the apparent effects on community structure persisted for the life of the post-disturbance Macrocystis pyrifera cohorts, despite relatively normal oceanographic conditions from 1985 to 1987 and relatively warm waters in recent years. 


\section{A. Articulated Corallines}

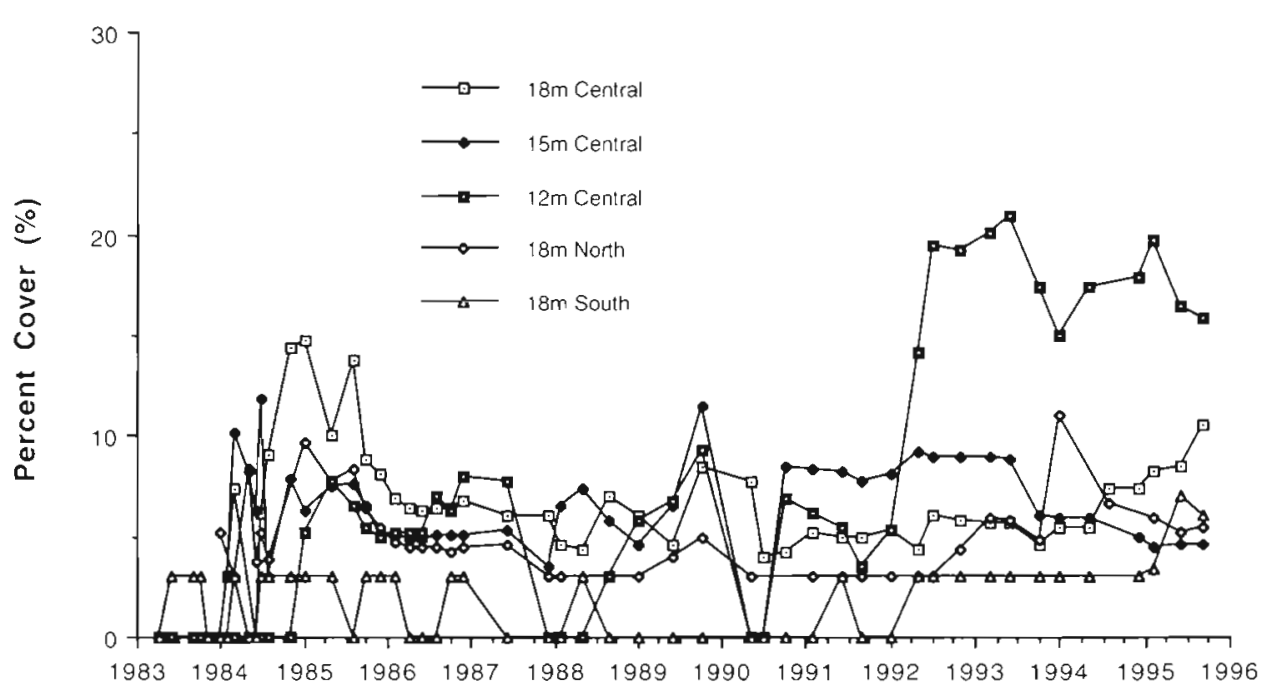

\section{B. Brown Turf (Dictyotaceae)}

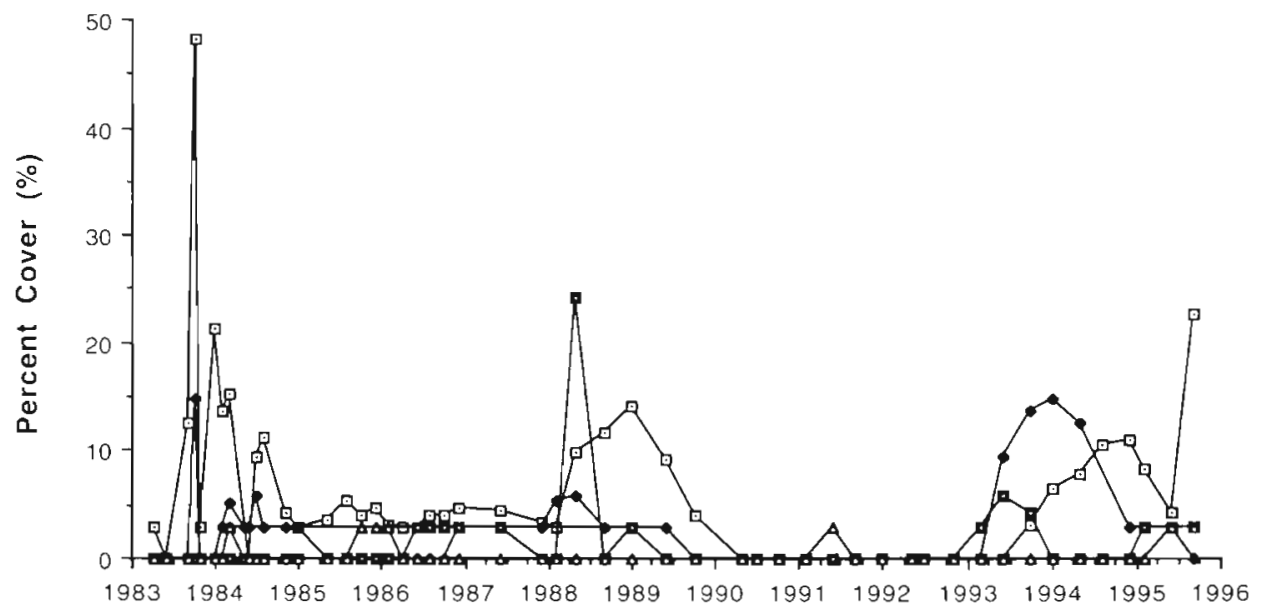

Fig. 10. Changes in percent cover of (A) articulated corallines and (B) brown turf algae (Dictyotaceae) at the 5 permanent sites, 1983 to 1995

Macrocystis pyrifera performance varied considerably over the study period. Intense recruitment followed both major disturbances, but there the similarities ended. Giant kelp plants that survived the 1982-1983 storms formed a sparse canopy in late spring, but the canopy began to deteriorate in summer, and by October, the tallest plants were 6 to $8 \mathrm{~m}$ below the surface; there was also substantial mortality of plants that survived the storms (Tegner \& Dayton 1987). New cohorts of adults recruited in summer and fall 1983, but these had poor growth (Dayton \& Tegner 1984) and survival relative to postdisturbance cohorts in 1988 (Fig. 5). Canopy area was very low in 1983-1985 before it began to recover; 1986 and 1987 were relatively normal years in terms of canopy coverage and oceanography (Fig. 2). Excellent growth conditions in 1988 were reflected in the more rapid post-storm recovery of the canopy and the better survival of initial post-disturbance cohorts (Fig. 5). Some M. pyrifera plants that had lost all their stipes in the 1988 storm produced new stipes and lived several months longer, whereas the nutrient-stressed plants damaged by the 1982-1983 storms generally had very poor survival and no recovery was observed of plants that had lost all their stipes (Dayton et al. 1992). Two years of anomalously cold water resulted in peaks in both canopy area and kelp harvest in 1990 (Fig. 2). The post-1988storm $M$. pyrifera cohorts showed their sensitivity to the relatively warm water, intermittent El Niño conditions of 1991-1993 with reductions in harvest and canopy area, poor growth in stipe number, and reduced carrying capacity, but apparently not through mortality (Figs. 2, 3 \&6). 
Comparisons with historical Macrocystis pyrifera stipe data indicated that the scope over which this parameter has varied is much larger than was observed between 1983 and 1994 (Tegner et al. 1996). Large samples taken in 1957 and 1974 near 15 m Central at Point Loma had median stipe counts of 55 and 41 per plant, respectively; in contrast, the highest median stipe count values from the post-disturbance populations at $15 \mathrm{~m}$ Central from this study were 26 in 1986 and 19 in 1993. Because there is an apparent hyperbolic relationship between average plant size and giant kelp densities, it is critical to compare stipe numbers at similar plant densities and stages in the selfthinning process (North 1994). All 4 samples were taken from mature stands with plant densities ranging from 0.08 to $0.2 \mathrm{~m}^{-2}$. These median stipe values appear to be inversely related to the sum of surface temperature anomalies for the preceding 36 mo. Rather than a dramatic indication of global warming, these data sets reflect the temperature climate at the times they were taken. Smith (1995) analyzed monthly SIO pier temperature anomalies for the period 1940 to 1993 for longer term variability using a 24 mo running mean. His results describe a long 1942-1957 cold period followed by the 1957-1959 El Niño, a cold period during 1960-1966, a brief 1966-1969 warm interval, a 1969-1976 cold period, and finally the extraordinary 1977-1993 warm period. The 1957 data were from plants which had grown through the longest cold interval in this record before the El Niño had had much impact in southern California; similarly, the 1974 data came from plants which integrated the 1969-1976 cold period. In contrast, the 17 yr warm water anomaly which started in 1977 and encompassed the data presented here was the longest in the 1922-1994 period for which SIO pier temperatures are available (Tegner et al. 1996). The two thirds reduction in median size of M. pyrifera plants between 1957 and 1993 suggests the potential for even more dramatic impacts on understory populations than were observed here.

Hierarchical competition for light among vertically arranged canopy layers of kelp guilds and other understory algae and an inverse resistance to storm disturbance among these guilds are well established elements of kelp forest community structure (e.g. Dayton et al. 1984, 1992, Reed \& Foster 1984, Foster \& Schiel 1985, Carr 1989), but less is known of temporal and spatial variability in these interactions. As Watanabe et al. (1992) asked: How frequent and intense must competition for light be to control spatial distribution and population structure? Kimura \& Foster (1984) found Macrocystis pyrifera and understory recruitment to be significantly greater following disturbance caused by summer kelp harvesting in central California. Pterygophora californica in that region showed physiologi- cal responses to harvesting of $M$. pyrifera canopies within a month (Watanabe et al. 1992), suggesting that population responses may be related to within-year variability in canopy cover of the competitive dominant. Recently, understory kelp abundance has been related to a gradient in physical disturbance; the more extreme the annual disturbance-induced fluctuations in giant kelp populations, the more abundant the understory (Harrold et al. 1988, Watanabe et al. 1992).

The understory kelps in the Point Loma kelp forest showed major successional differences after the 2 catastrophic-scale disturbances (Figs. 7 to 9). Like Macrocystis pyrifera, both understory species recruited strongly after the storm events, but subsequent fates were different under El Niño and La Niña conditions. From 1983 until the 1988 storm, Pterygophora californica persisted at 15 and especially $12 \mathrm{~m}$ Central and Laminaria farlowii at the 4 sites not subjected to sea urchin grazing. This contrasts markedly with plants recruiting after the 1988 storm; both species were virtually eliminated from all study sites for some period between 1990 and 1994. Evidence from concurrent clearing experiments suggest that the understory was competitively excluded by the La Niña $M$. pyrifera cohorts (P. Dayton, M. Tegner, P. Edwards \& K. Riser unpubl.). In 1988, clearings were established at 21, 15 , and $8 \mathrm{~m}$ depths in the center of the Point Loma forest for successional studies. Survivorship, growth, and reproduction of tagged kelps were followed under 2 treatments of $M$. pyrifera density, ambient (natural recruitment density) and low (1/3 ambient density). $L$. farlowii in the high density $M$. pyrifera treatments at both 15 and $8 \mathrm{~m}$ died within $1 \mathrm{yr}$; none of the plants at $8 \mathrm{~m}$ and only 2 out of 16 tagged plants at $15 \mathrm{~m}$ reproduced before death. L. farlowii in the high density treatment at $21 \mathrm{~m}$ had better survivorship, but only 1 plant was ever observed to be reproductive. In contrast, the low density $M$. pyrifera treatments had better L. farlowii survival, and some reproduction was observed in both 1989 and 1990 at all 3 depths (Dayton et al. unpubl.). These experiments indicate that $L$. farlowii survival and reproduction are sensitive to differences in the density of the overlying $M$. pyrifera plants. Thus, evidence from canopy area, harvest data, and the clearing experiments all support competitive exclusion of the understory from much of Point Loma during optimal La Niña growth conditions for $M$. pyrifera. Pearse \& Hines (1979) also documented a case of scramble competition among kelp guilds under good conditions for $M$. pyrifera growth leading to the virtual exclusion of understory species. With the exception of 1983, the Point Loma kelp forest was harvested throughout this study, but here there was no indication of annual peaks in the $P$. californica densities related to harvesting. In summary, large-scale oceanographic 
phenomena appear to be important to local kelp population dynamics and competitive interactions among kelp guilds. We conclude that nutrient stress does play a role in the competitive success of $M$. pyrifera.

There are spatial gradients of storm damage at Point Loma; giant kelp mortality increases with decreasing depth in the center of the forest and is higher at the north and south $18 \mathrm{~m}$ sites than at $18 \mathrm{~m}$ Central (Tegner \& Dayton 1987, Seymour et al. 1989, Dayton et al. 1992). These gradients, however, do not appear to be strong enough to cause the major differences in understory distribution observed in central California (Harrold et al. 1988, Watanabe et al. 1992). For example, $12 \mathrm{~m}$ Central suffered substantially higher giant kelp mortality than 15 and $18 \mathrm{~m}$ Central over the winter of 1986-1987 (Seymour et al. 1989), but this did not lead to Pterygophora californica recruitment. Smaller P. californica recruitment events took place after the 1986 urchin grazing event at $18 \mathrm{~m}$ South and self-thinning at $12 \mathrm{~m}$ Central in mid 1993 reduced Macrocystis pyrifera density to below $0.1 \mathrm{~m}^{-2}$. Laminaria farlowii recruited at $18 \mathrm{~m}$ South and $18 \mathrm{~m}$ North after urchin grazing reduced $M$. pyrifera density to less than $0.1 \mathrm{~m}^{-2}$, and after extensive self-thinning of giant kelp starting in 1993 at 3 other sites. P. californica responses after these local disturbances of the surface canopy were muted in comparison with periods after the major disturbances, probably due to the absence of major wave events (Reed et al. 1988), recent El Niño conditions, and/or reductions in supply of reproductive propagules after the La Niña event reduced understory populations.

Returning to the question of the frequency and intensity of competition for light necessary to control spatial distribution and population structure of understory kelps, several conclusions can be drawn from these data. Major storm disturbances appear to be required for large-scale understory recruitment at Point Loma. In contrast with Macrocystis pyrifera forests on the open coast of central California (e.g. Harrold et al. 1988, Watanabe et al. 1992), storms of the required magnitude are not an annual event experienced by giant kelp forests in the San Diego region. Similarly, harvesting is not an adequate disturbance to allow understory recruitment at Point Loma. The first 2 yr of a giant kelp cohort appear to govern understory populations for most of the lifetime of that $M$. pyrifera cohort. Oceanographic conditions during the first $2 \mathrm{yr}$ of a giant kelp cohort have a major effect on succession and the fate of understory species. Following the disturbance-induced scramble competitions, 2 yr of nutrient stress allowed persistence of the understory; 2 yr of cold, nutrient-rich conditions favored $M$. pyrifera dominance and led to the near extinction of understory species on our transects. The repeated stresses to $M$. pyrifera in 1982-1984, however, were not adequate to allow Pterygophora californica development to reach the point where it competitively excluded $M$. pyrifera, despite loss of the surface canopy 3 times in this $2 \mathrm{yr}$ period. A $M$. pyrifera clearing experiment established in fall 1984 at $12 \mathrm{~m}$ Central indicated that about $2.5 \mathrm{yr}$ of repeated disturbance (including 9 mo of total removal of giant kelp after the natural disturbances) were required for the $P$. californica canopy to become sufficiently dense to inhibit further giant kelp recruitment (Dayton et al. 1992).

It is clear that the relationships between Macrocystis pyrifera and understory abundances were not explicit functions of giant kelp density, stipe density, or harvest in this study; time lags between the peaks of giant kelp parameters and the point when $M$. pyrifera had declined sufficiently to allow for understory recruitment defy simple correlations within time series data. Significant negative correlations have been reported between $M$. pyrifera stipe density and percent understory cover for samples taken within 1 season (Carr 1989 , Fig. 3), or among years where the $M$. pyrifera canopy is annual (Cowen et al. 1982) and the understory is primarily composed of annuals (Foster \& Schiel 1985, Fig. 18). At Point Loma, there was a significant negative correlation between $M$. pyrifera and Pterygophora californica densities on 15 haphazardly chosen transects at depths of 12 to $18 \mathrm{~m}$ sampled during summer $1991\left(\mathrm{r}^{2}=0.519, \mathrm{p}=0.0025\right.$, data from Table 1 in Dayton et al. 1992). However, when annual mean data for the period 1984-1994 from the 12, 15, and $18 \mathrm{~m}$ sites are correlated, there is a significant positive relationship between abundances of the 2 kelps $\left(\mathrm{r}^{2}=0.48, \mathrm{p}=\right.$ 0.0001 ). This is due to high recruitment of both kelps after the major storm disturbances, followed by the decline in abundance of both of these perennials. Looking specifically at $15 \mathrm{~m}$ Central, the highest values of $M$. pyrifera density and stipe density in the time series occurred in 1989; the highest harvest for all of Point Loma was 1990. P. californica density was highest in 1988 and 1989 and declined precipitously in 1990; and, despite considerable reductions in all $M$. pyrifera parameters by 1992 during the 1992-1994 warm water period, $P$. californica did not recruit again until 1994. This time lag was probably not due to inappropriate temperatures for recruitment; there was spring upwelling in 1992, 1993, and 1994 (Fig. 2). M. pyrifera density dropped to $0.07 \mathrm{~m}^{-2}$ and stipe density to $1.5 \mathrm{~m}^{-2}$ at $15 \mathrm{~m}$ Central in 1994 , values that may be thresholds for understory kelp recruitment at this depth as both $P$. californica and Laminaria farlowii recruited in 1995. The thresholds for recruitment of the brown turf appear to be lower; the Dictyotaceae increased in percent cover in 1992 and 1993 at $15 \mathrm{~m}$ Central (Fig. 10B). Similarly, because both $P$. californica and $L$. farlowii survived at some sites until the 1988 
storm, we can infer that the levels of the $M$. pyrifera parameters which led to competitive exclusion of the understory are intermediate between the 1985 and the 1989 values. At $15 \mathrm{~m}$ Central, the understory persisted through a $M$. pyrifera density of 0.46 but not $0.8 \mathrm{~m}^{-2}$ and stipe densities of 6 but not $8 \mathrm{~m}^{-2}$. These thresholds for recruitment and competitive exclusion may define a density vague (sensu Strong 1984) relationship between $M$. pyrifera and understory kelps.

Do large-scale episodic events and non-equilibria conditions override biological or equilibria mechanisms as the dominant structuring roles in kelp forests? When we asked this question in 1991 (Dayton et al. 1992) on the basis of the 1983-1990 data, we concluded that the answer was no. After both catastrophic-scale disturbances, the winter storms of 1982-1983 and the single massive storm of 1988 , Macrocystis pyrifera quickly recovered its dominance along the transect iines at the 5 study sites, with some short-term lag effects due to Desmarestia spp. outbreaks or sea urchin grazing. However, in most areas, some patch structure of understory species persisted. With the perspective of 5 additional years of data, the importance of large-scale episodic events in structuring succession is clear. The La Niña of 1988-1989 led to such strong growth of $M$. pyrifera that the understory declined dramatically in 1991 and was largely absent from the transect lines at all 5 sites for a 2 yr period (Figs. 7 to 9). The short life of the effects was due to the biology of the dominant species; as the post1988-storm $M$. pyrifera cohorts died out in late 1993, the understory began to recover. Thus, for a 2 yr period some 2 yr after the event itself, a large-scale episodic process apparently did overwhelm the normal structuring mechanisms. We note that the lines at each site were established in 1983 in mixed stands of $M$. pyrifera and understory kelps that were severely damaged by the storms. Some established stands of understory kelps, notably Pterygophora californica, survived the storms and thus were not subjected to the same successional processes. For areas which were severely disturbed (most of the forest), ensuing La Niña conditions structured successional processes. At least since 1970, strong La Niñas have been less common than strong El Niños in the California Current region (T. Barnett pers. comm.), and neither is necessarily associated with severe storms (e.g. Seymour et al. 1984). Thus, the dramatic contrasts observed since 1983 in successional processes associated with large-scale oceanographic variability following major disturbances may represent extreme responses of this ecosystem.

The strong effects of ocean climate on kelp forest succession, competitive interactions, and kelp population dynamics reported here underscore the impor- tance of long-term studies for understanding how communities are structured. Interannual variability in temperature would have produced very different results in short-term studies at various time intervals within this study. El Niños and La Niñas are large-scale, low-frequency events with dramatic effects on the kelp forests of southern California, effects which require the tools of both pelagic and benthic ecology to be understood. The challenge to ecologists concerned with the regulation of community structure is how to integrate largescale, low-frequency variation into our studies of local processes in times of scarce resources for research.

Acknowledgements. We thank many divers for their field assistance over the last 13 yr, D. Glantz of Kelco for providing data, E. Venrick for statistical advice, T Hayward, J. McGowan, and C. Winant for continuing tutorials in oceanography, and L. Basch, M. Foster, M. Graham, E. Nestler, and E. Vetter for reviewing the manuscript. This research was funded by the National Science Foundation and the City of San Diego.

\section{LITERATURE CITED}

Boero F, Belmonte G, Fanelli G, Piraino S, Rubino F (1996) The continuity of living matter and the discontinuities of its constituents: do plankton and benthos really exist? Trends Ecol \& Evol 11:177-179

Carr MH (1989) Effects of macroalgal assemblages on the recruitment of temperate zone reef fishes. J Exp Mar Biol Ecol 126:59-76

Chelton DB, Bernal PA, McGowan JA (1982) Large-scale interannual physical and biological interaction in the California Current. J Mar Res 40:1095-1125

Connell JH, Keough MJ (1985) Disturbance and patch dynamics of subtidal marine animals on hard substrata. In: Pickett STA, White PS (eds) The ecology of natural disturbance and patch dynamics. Academic Press, Orlando, p $125-151$

Cowen RK, Agegian CR, Foster, MS (1982) The maintenance of community structure in a central California kelp forest J Exp Mar Biol Ecol 64:189-201

Dayton PK (1994) Communsty landscape: scale and stability in hard bottom marine communities. In: Giller PS, Hildrew AG, Raffaelli DG (eds) Aquatic ecology: scale, pattern and process. Blackwell Scientific, Oxford, p 289-332

Dayton PK, Currie V, Gerrodette T, Keller B, Rosenthal R, Ven Tresca D (1984) Patch dynamics and stability of some California kelp communities. Ecol Monogr 54:253-289

Dayton PK. Tegner MJ (1984) Catastrophic storms, El Niño. and patch stability in a California kelp community. $\mathrm{Scl}$ ence 224:283-285

Dayton PK, Tegner MJ (1990) Bottoms below troubled waters benthic impacts of the 1982-84 El Nino in the temperate zone. In: Glynn PW (ed) Ecological consequences of the 1982-83 El Niño to marine life. Elsevier Oceanography Series, No. 52, Amsterdam, p 433-472

Dayton PK, Tegner MJ, Parnell PE, Edwards PB (1992) Temporal and spatial patterns of disturbance and recovery in a keip forest community. Ecol Monogr 62:421-445

Dean TA, Jacobsen FR (1984) Growth of Juvenile Macrocystis pyrifera (Laminanales) in relation to environmental factors. Mar Biol 83:301-311 
Dean TA, Jacobsen FR (1986) Nutrient-limited growth of juvenile kelp, Macrocystis pyrifera, during the 1982-84 'El Niño' in southern California. Mar Biol 90:597-601

Devinny JS, Volse LA (1978) Effects of sediments on the development of Macrocystis pyrifera gametophytes. Mar Biol 48:343-348

Deysher LE, Dean TA (1984) Critical irradiance levels and the interactive effects of quantum irradiance and dose on gametogenesis in the giant kelp, Macrocystis pyrifera. J Phycol 20:520-524

Deysher LE, Dean TA (1986a) Interactive effects of light and temperature on sporophyte production in the giant kelp. Macrocystis pyrifera. Mar Biol 93:17-20

Deysher LE, Dean TA (1986b) In situ recruitment of grant kelp, Macrocystis pyrifera (L.) C. A. Agardh: effects of physical factors. J Exp Mar Biol Ecol 103:41-63

Foster MS (1975a) Algal succession in a Macrocystis pyrifera forest. Mar Biol 32:313-329

Foster MS (1975b) Regulation of algal community development in a Macrocystis pyrifera forest. Mar Biol 32:331-342

Foster MS, Schiel DR (1985) The ecology of giant kelp forests in Calıfornia: a community profile. US Fish Wildl Serv Biol Rep 85 (7.2)

Gerard V (1982) Growth and utilization of internal nutrogen reserves by the giant kelp Macrocystis pyrifera in a lownitrogen environment. Mar Biol 66:27-35

Giller PS, Hildrew AG, Raffaelli DG (eds) (1994) Aquatic ecology: scale, pattern and process. Blackwell Scientific Oxford

Graham NE (1994) Decadal-scale climate variability in the tropical and North Pacific during the 1970s and 1980s: observations and model results. Clim Dyn 10:135-162

Hall SJ, Raffaelli D, Thrush SF (1994) Patchiness and disturbance in shallow water benthic assemblages. In: Giller PS, Hildrew AG, Raffaelli DG (eds) Aquatic ecology: scale, pattern and process. Blackwell Scientific, Oxford, $p$ $333-375$

Harrold C, Watanabe JM, Lisin S (1988) Spatial varlation in the structure of kelp forest communities along a wave exposure gradient. PSZN I Mar Ecol 9:131-156

Hayward TL (in press) Pacific Ocean climate change: atmospheric forcing, ocean circulation and ecosystem response. Trends Ecol Evol

Hayward TL (1993) Preliminary observations of the 19911992 El Niño in the California Current. California Cooperative Oceanic Fisheries Investigations Rep 34:21-30

Hayward TL, Cayan DR, Franks PJS, Lynn RJ, Mantyla AW, McGowan JA, Smith PE, Schwing FB, Venrick EL (1995) The state of the California Current in 1994-1995: a period of transition. California Cooperative Oceanıc Fisheries lnvestigations Rep 36:19-39

Hayward TL, Mantyla AW, Lynn RJ, Smith PE, Chereskin TK (1994) The state of the Calıfornia Current in 1993-1994 California Cooperative Oceanic Fisheries Investigations Rep 35:19-35

Jackson GA (1977) Nutrients and production of giant kelp. Macrocystis pyrifera, off southern California. Limnol Oceanogr 22:979-995

Jackson GA (1987) Modelling the growth and harvest yield of the giant kelp Macrocystis pyrifera. Mar Biol 95:611-624

Kennelly SJ (1987a) Physical disturbance in an Australian kelp community. I. Temporal effects. Mar Ecol Prog Ser 40: $145-153$

Kennelly SJ (1987b) Physical disturbance in an Australian kelp community. II. Effects on understorey species due to differences in kelp cover. Mar Ecol Prog Ser 40:155-165

Kennelly SJ, Underwood A.J (1993) Geographic consistencies of effects of experimental physical disturbance on understorey species in sublittoral kelp forests in New South Wales. J Exp Mar Biol Ecol 168:35-58

Kerr RA (1988) La Niña's big chill replaces El Niño. Science 241:1037-1038

Kimura RS, Foster MS (1984) The effects of harvesting Macrocystis pyrifera on the algal assemblage in a giant kelp forest. Hydrobiologia 116/117:425-428

Lobban CS, Harrison PJ, Duncan, MJ (1985) The physiological ecology of seaweeds. Cambridge University Press, Cambridge

Murray SN, Bray RN (1993) Benthic macrophytes. In: Dailey MD, Reish DJ, Anderson JW (eds) Ecology of the southern Calıfornia Bight. University of Californa Press, Berkeley, p $304-368$

North WJ (1971) Introduction and background. In: North WJ (ed) The biology of giant kelp beds (Macrocystıs) in California. Cramer, Lehre, Germany, p 123-168

North WJ (1994) Review of Macrocystis biology. In: Akatsuka I (ed) Biology of economic algae. SPB Acadennc Publishing bv, The Hague, p 447-527

North WJ, Jackson GA, Manley SL (1986) Macrocystis and its environment, knowns and unknowns. Aquat Bot 26:9-26

North WJ, James DE, Jones LG (1993) History of kelp beds (Macrocystis) in Orange and San Diego Counties, California. Hydrobiologia 260/261:277-283

North WJ, Zimmerman, RC (1984) Influences of macronutrients and water temperature on summertime survival of Macrocystis canopies. Hydrobiologia 116/117:419-424

Odum EP (1981) The effects of stress on the trajectory of ecological succession. In: Barrett GW, Rosenberg R (eds) Stress effects on natural ecosystems. John Wiley \& Sons. Ltd, Chichester, UK, p 43-47

Pearse JS. Hines AH (1979) Expansion of a central California kelp forest following the mass mortality of sea urchins. Mar Biol 51:83-91

Polovina JJ, Mitchum GT, Graham NE, Craig MP, Demartini EE, Flint EN (1994) Physical and biological consequences of a climate event in the central North Pacific. Fish Oceanogr 3:15-21

Reed DC, Foster MS (1984) The effects of canopy shading on algal recruitment and growth in a giant kelp forest. Ecology $65: 937-948$

Reed DC, Laur DR, Ebeling AW (1988) Variation in algal dispersal and recruitment: the importance of episodic events Ecol Monogr 58:321-335

Schroeter SC, Dean TA, Thies K, Dixon JD (1995) The effects of shading by adults on the growth of blade-stage Macrocystis pyrifera (Phaeophyta) during and after the 1982-84 El Niño. J Phycol 31:697-702

Seymour RJ (1989) Wave observations in the storm of $17-18$ January, 1988. Shore \& Beach 57:10-13

Seymour RJ, Strange RR III, Cayan DR, Nathan RA (1984) Influence of El Niños on California's wave climate. In: Edge BL (ed) Nineteenth Coastal Engineering Conference, Proceedings of the International Conference, Sept. 3-7, 1984, Houston, Texas. Am Soc Civil Engineers, New York, Vol I, p 577-592

Seymour RJ. Tegner MJ, Dayton PK, Parnell PE (1989) Storm wave induced mortality of giant kelp, Macrocystis pyrifera, in southern California. Estuar Coast Shelf Sci 28: $277-292$

Smith PE (1995) A warm decade in the California Current. California Cooperative Oceanic Fisheries Investigations Rep 36:120-126

Sousa WP (1985) Disturbance and patch dynamics on rocky intertidal shores. In: Pickett STA, White PS (eds) The ecol- 
ogy of natural disturbance and patch dynamics. Academic Press, Orlando, p 101-124

Strong DR (1984) Density-vague ecology and liberal population regulation in insects. In: Price PW, Slobdchikoff $C N$, Gaud WS (eds) A new ecology: novel approaches to interactive systems. John Wiley \& Sons, New York, p 313-327

Tegner MJ, Dayton PK (1987) El Niño effects on southern California kelp forest communities. Adv Ecol Res 17:243-279

Tegner MJ, Dayton PK (1991) Sea urchins, El Niños, and the long term stability of southern California kelp forests. Mar Ecol Prog Ser 77:49-63

Tegner MJ, Dayton PK, Edwards PB, Riser KL (1995b) Sea urchin cavitation of giant kelp (Macrocystis pyrifera C. Agardh) holdfasts and its effects on kelp mortality across a large California forest. J Exp Mar Biol Ecol 191:83-99

Tegner MJ, Dayton PK, Edwards PB, Riser KL (1996) Is there evidence for long-term climatic change in southern California kelp forests? California Cooperative Oceanic Fisheries Investigation Rep 37:111-126

Tegner MJ, Dayton PK, Edwards PB, Riser KL, Chadwick DB, Dean TA, Deysher L (1995a) Effects of a large sewage spill on a kelp forest community: catastrophe or disturbance? Mar Environ Res 40:181-224

This article was submitted to the editor
Turkington R, Klein E, Chanway CP (1993) Interactive effects of nutrients and disturbance: an experimental test of plant strategy theory. Ecol 74:863-878

Watanabe JM, Phillips RE, Allen NH, Anderson WA (1992) Physiological response of the stipitate understory kelp, Pterygophora californica Ruprecht, to shading by the giant kelp, Macrocystis pyrifera C. Agardh. J Exp Mar Biol Ecol 159:237-252

Wheeler PA, North WJ (1980) Effect of nitrogen supply on nitrogen content and growth rate of juvenile Macrocystis pyrifera (Phaeophyta) sporophytes. J Phycol 16: $577-582$

Zimmerman RC, Kremer JN (1984) Episodic nutrient supply to a kelp forest ecosystem in southern California. J Mar Res 42:591-604

Zimmerman RC. Kremer JN (1986) In situ growth and chem1cal compostion of giant kelp, Macrocystis pyrifera: response to temporal changes in ambient nutrient availability. Mar Ecol Prog Ser 27:277-285

Zimmerman RC, Robertson DL (1985) Effects of El Niño on local hydrography and growth of the giant kelp, Macrocystis pyrifera, at Santa Catalina Island, California. Limnol Oceanogr 30:1298-1302

Manuscript first received: May 28, 1996

Revised version accepted: October 14, 1996 